\title{
JERUSALEM ARTICHOKE (HELIANTHUS TUBEROSUS) FLOUR IMPACT ON BREAD QUALITY
}

\author{
Aurica Chirsanova ${ }^{1}$, ORCID: 0000 -0002-1172-9900, \\ Tatiana Capcanari ${ }^{1}$, ORCID: 0000-0002-0056-5939, \\ Ecaterina Gîncu², ORCID ID: 0000-0001-6267-2310 \\ ${ }^{1}$ Technical University of Moldova, 168, Stefan cel Mare Bd., Chisinau, Republic of Moldova \\ ${ }^{2}$ Academy of Economic Studies of Moldova, 61 Bănulescu-Bodoni Street, Chișinau, Republic of Moldova \\ ${ }^{*}$ Corresponding author: Aurica Chirsanova, aurica.chirsanova@toap.utm.md \\ Received: 01. 23. 2021 \\ Accepted: 02. 25. 2021
}

\begin{abstract}
Jerusalem artichoke tubers are known for their high content of nutrients, high acidity, pleasant taste and smell and beneficial effects on health. Thus, the capitalization of food products such as bread with Jerusalem artichoke flour, could be an opportunity to diversify the range of new products. The aim of this research was to elucidate the impact of added Jerusalem artichoke flour (in a concentration of $2.5 \%, 5 \%, 7.5 \%$ and $10 \%$ ) in wheat flour bread on the sensory and physico-chemical properties of the finished product. Jerusalem artichoke flour has a high dry matter content and a high content of essential amino acids such as histidine, isoleucine, methionine, phenylalanine and valine. In the results we recommend the replacement of wheat flour with $5 \%$ Jerusalem artichoke flour, to obtain a product rich in micro and macronutrients with better organoleptic properties and a longer shelf life, which positively influences human health.
\end{abstract}

Keywords: Jerusalem artichoke, dough fermentation, bread volume, organoleptic properties.

\section{Introduction}

Jerusalem artichoke (Helianthus tuberosus), also called "soil apple", "pork turnip", "guli", "potato of the poor" (from Hungarian), "Jerusalem artichoke" is a plant of the Asteraceae family, belonging, like the flower of the sun, the genus Helianthus. It is native to eastern North America, and the name Jerusalem artichoke comes from the Native American tribe "Topinambas" [1].

Jerusalem artichoke (Helianthus tuberosus) is a perennial plant which consists of a stem about 1-3 m tall, small yellow flowers, hairy oval shaped leaves and an underground rhizome system which bears small tubers. It is an Angiosperm plant species of the Composite family, which is commonly referred to as the sunflower or daisy family. The stems are stout and ridged which can become woody overtime. Its leaves alternate near the top of the stem, the lower leaves are larger and broader, and can grow up to $30 \mathrm{~cm}$ long while the higher ones are smaller and narrower. In terms of flower heads, each is $5-7.5 \mathrm{~cm}$ wide and formed by small, yellow, tubular disk flowers in the center and surrounded by 
florets, which occur separately or in groups at the end of alar branches and main stems. As for tubers, they are uneven and elongate varying from knobby to round clusters. The colors of tubers range from pale brown to white, red and purple [2].

Over the years, within the Botanical Gardens of the Academy of Sciences of Moldova there was collected a collection of over 60 Jerusalem artichoke taxa with different periods of vegetation, plant habitus, shape and coloration of tubers, which serves as a material for improving the species, being selected perspective forms for the creation of new varieties. Among the perspective varieties in the collection are the Solar variety (harvest up to $44 \mathrm{t} /$ ha) and Amicul II, created by clonal selection from large populations, registered in the catalog of plant varieties of the Republic of Moldova since 2014 [3].

It is known that due to its unique chemical composition, Jerusalem artichoke tubers can be used as a raw material for the industrial manufacture of flour, inulin, syrup and glucose-fructose powder, pectin, alcohol and various finished foods. The use of Jerusalem artichoke in food is quite diverse and includes juices, purees, syrups, fermented beverages, bakery products, etc. $[4,5]$. Jerusalem artichoke juices can be natural or mixed with other fruit or vegetable juices, clarified or concentrated [6].

Jerusalem artichoke is a plant with a number of advantageous characteristics over traditionally agricultural crops, including high growth rate, good tolerance to frost, drought and poor soil, strong resistance to pests and plant diseases, with minimal to zero fertilizer requirements. Conventionally, Jerusalem artichoke has been used for food or animal feed, and for the past two decades, alternative uses have been explored especially for the production of functional food ingredients such as inulin, oligofructose and fructose. It is also found that some bioactive ingredients can be extracted from its leaves and stems, which creates an opportunity for applications in the pharmaceutical sector [7, 8].

In recent times, special attention has been paid to fermented beverages. It was demonstrated that inulin hydrolysis to reducing sugars from Jerusalem artichoke juice and its fermentation with homofermentative bacteria Pediococcus acidilactici DQ2 ensures high lactic acid productivity $[9,10,11]$.

Several researches have been carried out in the Russian Federation in order to process Jerusalem artichoke in purees [12]. At the same time, several combinations of Jerusalem artichoke purees and pastas, fruits (apples, bananas, pears) and vegetables (carrots, pumpkins, eggplants) with pectin additives, nuts, bran were developed, intended for people suffering from diabetes $[13,14]$. Jerusalem artichoke purees can be used as food or as additives in the manufacture of other foodstuffs $[15,16]$.

Another valuable product is Jerusalem artichoke flour which has a very low fat content, low caloric value and can be used for partial substitution (up to 10\%) of wheat flour in the manufacture of bread and pastries but also as a functional agent in other foods $[17,18]$.

In order to protect the bioactive components (vitamins, phenolic compounds, etc.) from Jerusalem artichoke tubers, they can also be subjected to a convective drying process at $50^{\circ} \mathrm{C}$. The flour is characterized by the content of inulin-type (51.60 ... 52.24\%), fiber (6.85 ... 7.67\%), total polyphenols (18.51 ... $44.03 \mathrm{mg} \mathrm{GAE} \mathrm{/} \mathrm{g),} \mathrm{protein} \mathrm{(8.75} \mathrm{...} 9.01 \%$ ), iron (12.45 ... $12.78 \mathrm{mg} / 100 \mathrm{~g})$, potassium (1905.44 ... $1912.85 \mathrm{mg} / 100 \mathrm{~g})$, calcium (50.21 ... $51.12 \mathrm{mg} / 100 \mathrm{~g})$, magnesium (84.55 ... $86.85 \mathrm{mg} / 100 \mathrm{~g})$ and phosphorus content (300.12 ... $316.62 \mathrm{mg} / 100 \mathrm{~g}$ ). At the same time, the flour obtained from Jerusalem artichoke tubers has a high antioxidant potential [19]. 
The tubers of Jerusalem artichoke are rich in protein (3.2\%, dry matter). Jerusalem artichoke proteins contain many amino acids (16), including 10 essential (they are not produced by the human body and come from food): arginine, valine, histidine, isoleucine, leucine, lysine, methionine, threonine, tryptophan, phenylalanine.

According to the Novosibirsk Scientific Research Institute of Clinical Immunology SB RAMS, these protein compounds are very close in structure to proteins of the thymus gland (thymus) - they have practically identical properties to those of thymus, major regulators of maturation and functional activity of cells of the immune system [20].

The Jerusalem artichoke is rich in pectin (approximately $11 \%$ of dry matter weight). Pectin's are high molecular weight carbohydrates that make up the cell membrane and intercellular substance. Pectin's have absorbent, astringent and thickening properties. They reduce the level of cholesterol in the body, improve metabolic processes, normalize bowel movements, and improve the peripheral circulation. But the most valuable feature of pectin is its ability to clear up the organisms without leaving any 'garbage' and not breaking of the balance of the internal body environment.

Currently, Jerusalem artichoke flour has been proposed for the manufacture of articles from leavened, sandy, tender, sponge dough and pasta [21, 22]. The administration of Jerusalem artichoke flour improves the porosity of bakery products and their sensory qualities. At the same time, the glycemic index of the finished products decreases, which is important for patients with diabetes and obesity [23, 24]. Noodle dough prepared with the addition of Jerusalem artichoke flour (compared to that of durum wheat flour) has a waterbinding capacity and increased elasticity and low adhesiveness [25].

Bread has been considered one of the staple foods for centuries in many countries and is an important part of the diet. For example, the average volume of bakery and flour products consumed in the Republic of Moldova between 2012 and 2017 was 102.6 [26]. Based on the above, the purpose of the research in this article was to present the impact of the addition of Jerusalem artichoke flour obtained from the Solar and Amicu II variety on the quality of bread.

\section{Materials and methods}

Jerusalem artichoke flour used for research was obtained from tubers of the "Amicu II" and "Solar" variety, harvested at the Institute of Phytotechnics in Porumbeni, Chisinau.

The dry matter, ash content and titratable acidity of Jerusalem artichoke flour were determined using the methods described in ISO 6540: 2010 ISO 763: 2003 and ISO 750: $1998[27,28]$.

Flour quality indicators, wet gluten content, acidity were analyzed according to international standard methods.

\subsection{Jerusalem artichoke flour obtaining}

Before use, the tubers were packed and stored in the refrigerator at $4^{\circ} \mathrm{C}$. Before drying, the tubers were washed and cut into rounds using an electric slicer. The thickness of the obtained washers is $1 \mathrm{~mm}$. The initial humidity of the tubers was $75.96 \%(3.15997 \mathrm{~kg}$ water / kg dry matter, 315.97\% / DM).

\subsection{Atomic absorption spectroscopy (AAS)}

Is a spectroanalytical procedure for the quantitative determination of chemical elements using the absorption of optical radiation by free atoms in the gaseous state. 
Atomic absorption spectroscopy is based on absorption of light by free metallic ions For analysis, the samples were mixed with the required solvents. A series of working samples have been prepared from the solution. The atomic absorption spectrometer were adjusted for each of the studied elements. The sample were introduced into an atomizer, after which calibration solutions are added.

\subsection{Dry matter in Jerusalem artichoke flour samples}

For determination of dry matter content the flour samples were dried at a temperature between $130 \pm 2{ }^{\circ} \mathrm{C}$, until a constant mass of dry residue was obtained.

\subsection{Insoluble ash in hydrochloric acid}

The determination of the ash content was carried out by calcining the flour sample at a temperature of $550-600^{\circ} \mathrm{C}$ to a constant mass.

\subsection{Titratable acidity}

The acidity index is the amount of $\mathrm{NaOH}(1 \mathrm{~N} \mathrm{NaOH} / 100 \mathrm{~g}$ of matter) required to neutralize one gram of product in the presence of phenolphthalein as an indicator.

\subsection{Amino acids in Jerusalem artichoke flour}

The amino acid content of Jerusalem artichoke flour was determined using the high performance liquid chromatographic (HPLC) method. In was used the gradient HPLC Agilent 1100 series. The HPLC instrument was equipped with an auto-injector, column compartment, fluorescent detector (G1315B), vacuum degasser and quaternary pump. Separation was performed on the Eclipse XDB C18 column (ID $2.1 \times 150 \mathrm{~mm}, 5 \mu$ particle size) at $40^{\circ} \mathrm{C}$. Peak monitoring was performed on a fluorescent detector with excitation wavelength $\lambda$ ex340 $=\mathrm{nm}$ and emission $\lambda$ em $=450 \mathrm{~nm}$.

\subsection{The impact of wheat flour substitution with Jerusalem artichoke flour on bread volume}

The specific volume of the breads $(\mathrm{cm} 3 / \mathrm{g})$ is measured indirectly by moving small spherical solid particles with known specific volume in a container where the final bread is placed.

The measure consists in emptying the container up to half its solid particle content, over which the bread is placed and covered, the sample with the rest of the grains.

After leveling the surface of the measuring vessel, the volume of excess spherical grains corresponds to that of the bread. Thus, the specific volume of bread (Vsp) expressed in $\mathrm{cm} 3$ / $\mathrm{g}$ represents the ratio between the coefficient of bread volume $(V)$ and its mass (M).

\subsection{Sensory analysis of bread samples}

The sensory evaluation of the obtained products was performed using a 30-point scale method [29]. Bread receiving between 24.1 and 30 points is considered to be of very good quality; between 18.1 and 24.0 points is of good quality; between 12.1 and 18.0 points is a satisfactory quality; between 6.1 and 12.0 is of poor quality; between 0.1 and 6.0 is a very poor quality. 
The shape, surface of the crust, color, appearance in section, consistency of the crumb, taste and smell was evaluated by a tasters group. The criteria in Table 1 were used to quantify sensory characteristics.

\subsection{Statistical analysis}

All samples were analyzed in triplicate, and standard deviations are given in order to assess the repeatability of the methods used. Variance analysis of the results was carried out by least square method with application of Microsoft Office Excel program.

\section{Results and discussions}

\subsection{Jerusalem artichoke flour characteristic}

To obtain Jerusalem artichoke flour, the tubers were washed, dried and cut into 1 $\mathrm{mm}$ thick slices. The initial humidity of the tubers was $75.96 \%$ (3.15997 kg water / kg dry matter, 315.97\% / DM).

The characterization of the flour is done using specific values: ash content, moisture, protein content, gluten content, baking power and others. All these features make it possible to understand the use of flour, whether it is intended for the manufacture of bread, biscuits or other products.

The two varieties of Jerusalem artichoke in the studio (Amicul II and Solar) have quite close physico-chemical indices. At the same time, from table 1 we notice that the flour obtained from the Jerusalem artichoke tubers of the Amicul II variety has a higher content of macro and microelements (table 1).

Table 1

Physico-chemical indices of Jerusalem artichoke flour

\begin{tabular}{lccc}
\hline \multicolumn{1}{c}{ Variety } & Humidity\% & Ash,\% & Acidity degrees \\
\hline Amicul II & 13,4 & 5,25 & 3,1 \\
\hline Solar & 14,2 & 4,11 & 3,2 \\
\hline \multicolumn{4}{c}{ Macroelements, $\mathbf{~ m g ~ / ~ 1 0 0 g ~}$} \\
\hline Amicul II & Potassium & Calcium & Magnesium \\
\hline Solar & $18919 \pm 45$ & $1014 \pm 12$ & $294 \pm 3$ \\
\hline \multicolumn{4}{c}{ Microelements, $\mathbf{~ m g / 1 0 0 g}$} \\
\hline Amicul II & $10671 \pm 23$ & Copper & Zinc \\
\hline Solar & Iron & $1,69 \pm 0,4$ & $5,91 \pm 0,5$ \\
\hline
\end{tabular}

The protein content of Jerusalem artichoke flour and wheat flour was $2.4 \%$ and $11.9 \%$, respectively. This content is higher than $7 \%$, which corresponds to the minimum set by the Codex Alimentarius (FAO, 1996).

The content of amino acids in Jerusalem artichoke flour proteins of two varieties is shown in Figure 2, where we see that the dominant amino acids are glutamic acid and aspartic followed by the rest of the amino acids.

The protein content of wheat flour used in this study could compensate deficit of protein in the Jerusalem artichoke mass. 


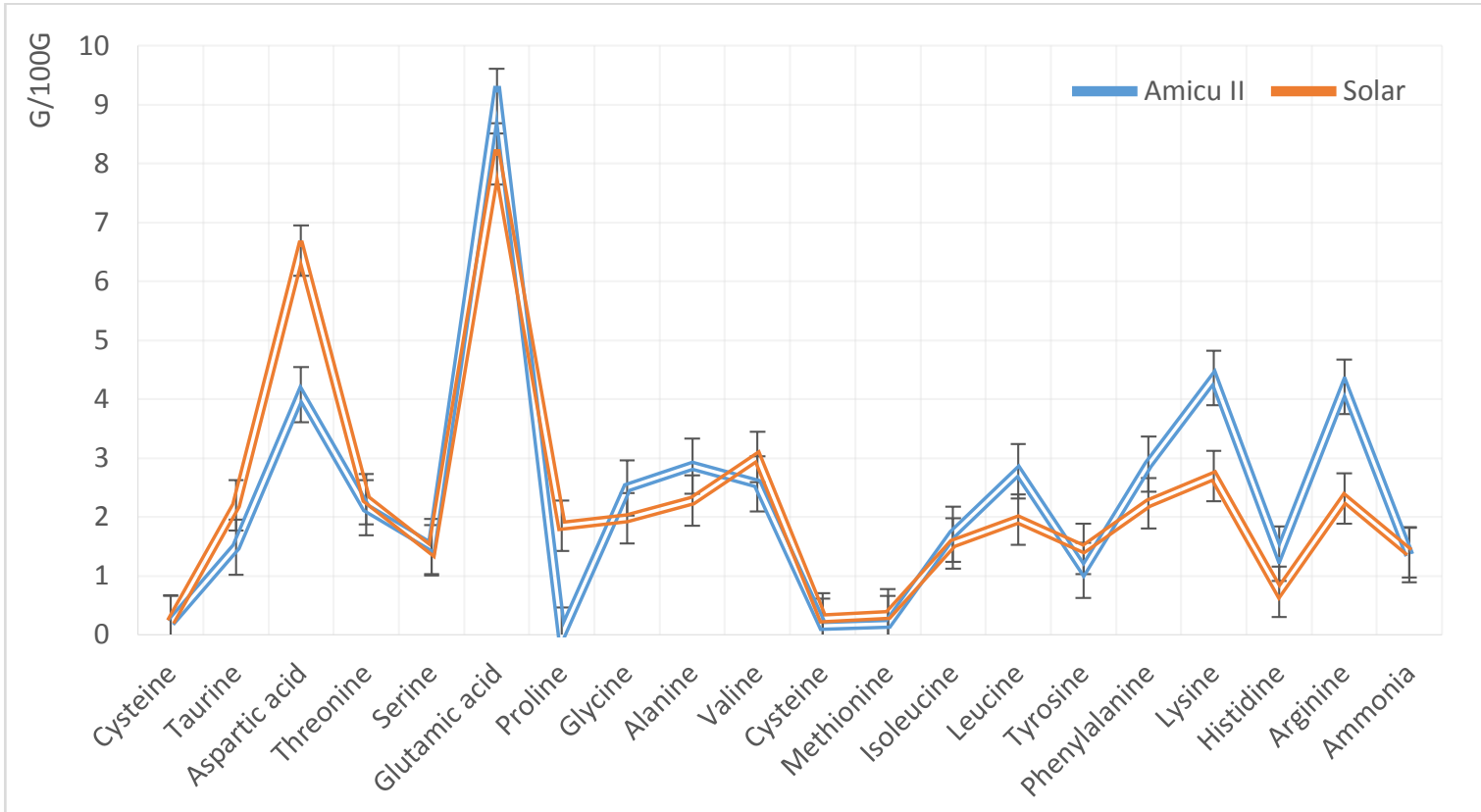

Figure 2. The content of amino acids in proteins of Jerusalem artichoke flour.

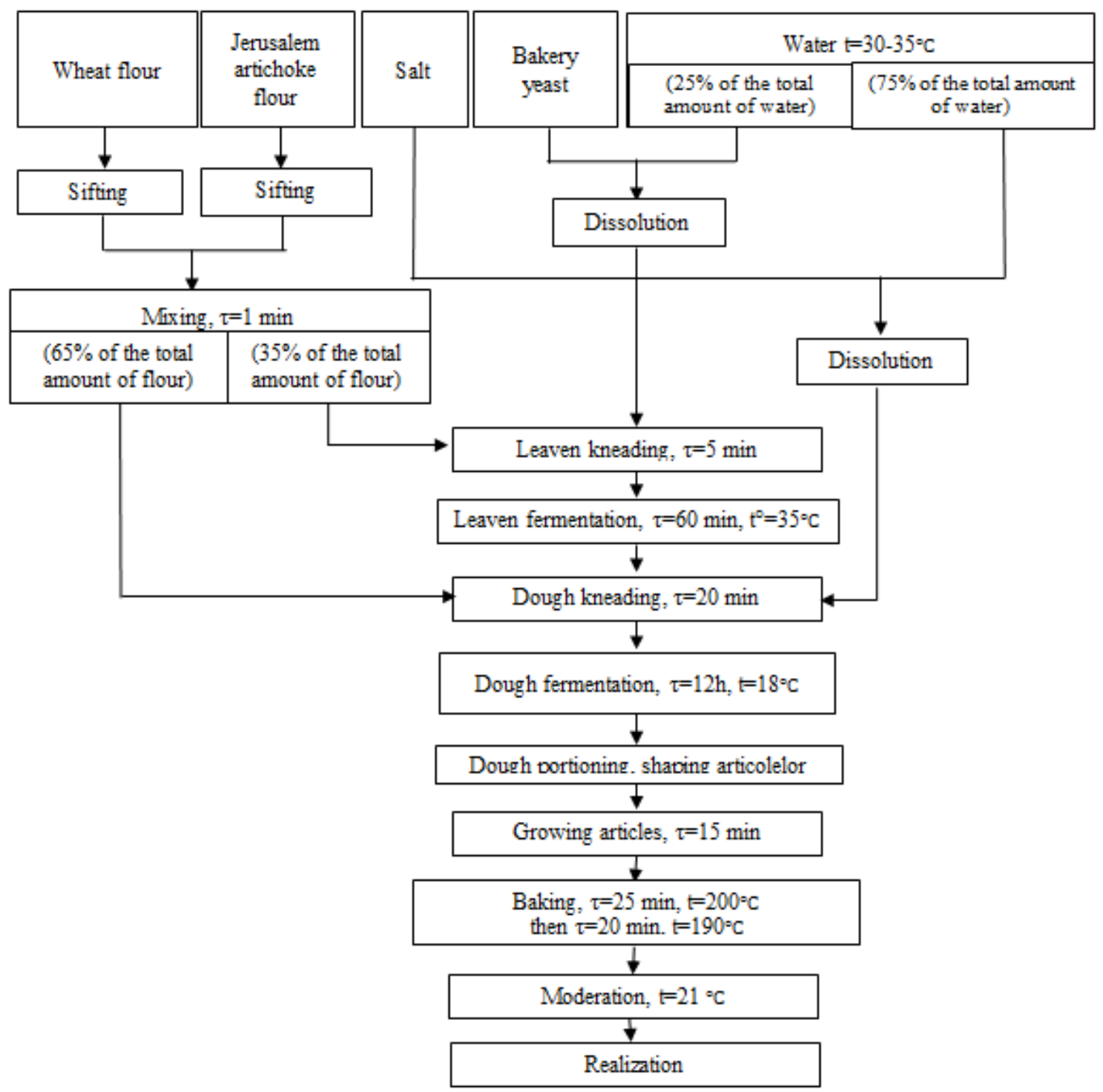

Figure 3. General scheme of bread making [developed by the authors]. 


\subsection{Bread obtaining}

The bread was obtained in the laboratory of culinary technology within the Department of Food and Nutrition, Faculty of Food Technology, Technical University of Moldova, by the indirect method according to the technological scheme presented in Figure 3.

\subsection{Titratable acidity during dough kneading and fermentation}

During kneading and fermentation, the acidity of the dough increases. This increase is caused by acid reactions. The titratable acidity values of wheat flour and Jerusalem artichoke are shown in Table 2.

Table 2

The evolution of titratable acidity during dough kneading and fermentation

\begin{tabular}{cccccccccc}
\hline Time, & Wheat & Solar & Solar & Solar & Solar & Amicu II & Amicu II & Amicu II & Amicu II \\
minutes & $\begin{array}{c}\text { flour, } \\
\text { control } \\
\text { sample }\end{array}$ & $2,5 \%$ & $5 \%$ & $7,5 \%$ & $10 \%$ & $2,5 \%$ & $5 \%$ & $7,5 \%$ & $10 \%$ \\
\hline 30 & 1,4 & 2,2 & 2,8 & 3,4 & 3,6 & 1,8 & 3,0 & 3,2 & 4,0 \\
\hline 60 & 2,8 & 3,2 & 3,8 & 5,0 & 6,4 & 3,2 & 4,6 & 6,2 & 6,6 \\
\hline
\end{tabular}

The increase in dough acidity is due to the formation and accumulation of lactic, acetic, succinic, malic, formic, tartaric, citric and other organic acids. The accumulation of lactic acid and acetic acid is considered to be the result of fermentation caused by lactic acid heterofermentative bacteria. Alcoholic fermentation, caused by yeast cells, leads to the formation of very small amounts of succinic acid in the dough.

\subsection{Evolution of the volume of the dough during fermentation}

Fermentation is a specific stage of bakery products and has the role of enriching the dough with carbon dioxide. This process is complex and causes a loss of total matter (from 2 to $3 \%$ ) by converting sugars into alcohol and carbonic acid [30]. Fermentation is generated by the action of yeasts on the sugars present in the dough which transforms them into alcohol and carbon dioxide, with energy production [31, 32].

Replacing wheat flour with Jerusalem artichoke flour slows the growth of the dough. The optimal fermentation period is 80 - 100 minutes with a gas expansion between $125 \%$ for the dough with a content of $10 \%$ Jerusalem artichoke flour and $154 \%$ - for the one containing $5 \%$ Jerusalem artichoke flour.

The share of added artichoke flour from Jerusalem in Amicul II and Solar juice in a concentration of $2.5 \%, 5 \%, 7.5 \%$ and $10 \%$ of the volume of dough growth during fermentation is shown in Figure $4 a$ and $4 \mathrm{~b}$ for each variety. respectively. The doughs obtained by adding artichoke flour from Jerusalem in different concentrations were tested to observe their stability by determining the optimal fermentation time. Tracking the progress of the volume of dough (wheat flour + artichoke flour) in fermentation (temperature $30^{\circ} \mathrm{C}$ ) showed that the fermentation rate increased in the first 20-50 minutes, probably due to fermentable carbohydrates that are generally in small quantities in cereal flour (1.0 -1.5\%) which are of particular importance in initiating the fermentation process (consumed in the first half hour of the fermentation process). 
The dough mixes reached maximum volume values after 80 minutes of fermentation, and the volume of the dough remains relatively stable. During the fermentation process, the dough samples with the addition of Jerusalem artichoke flour in a concentration of $7.5 \%$ and $10 \%$ contributed to a slow increase in the volume of the dough.

The addition of Jerusalem artichoke flour generally has an effect beneficial on the volume of the dough, which contributed to a good fermentation and stability of the dough. Contribution optimal amount of Jerusalem artichoke flour was 2.5 (Solar variety) and 5\% (Amicul II variety).

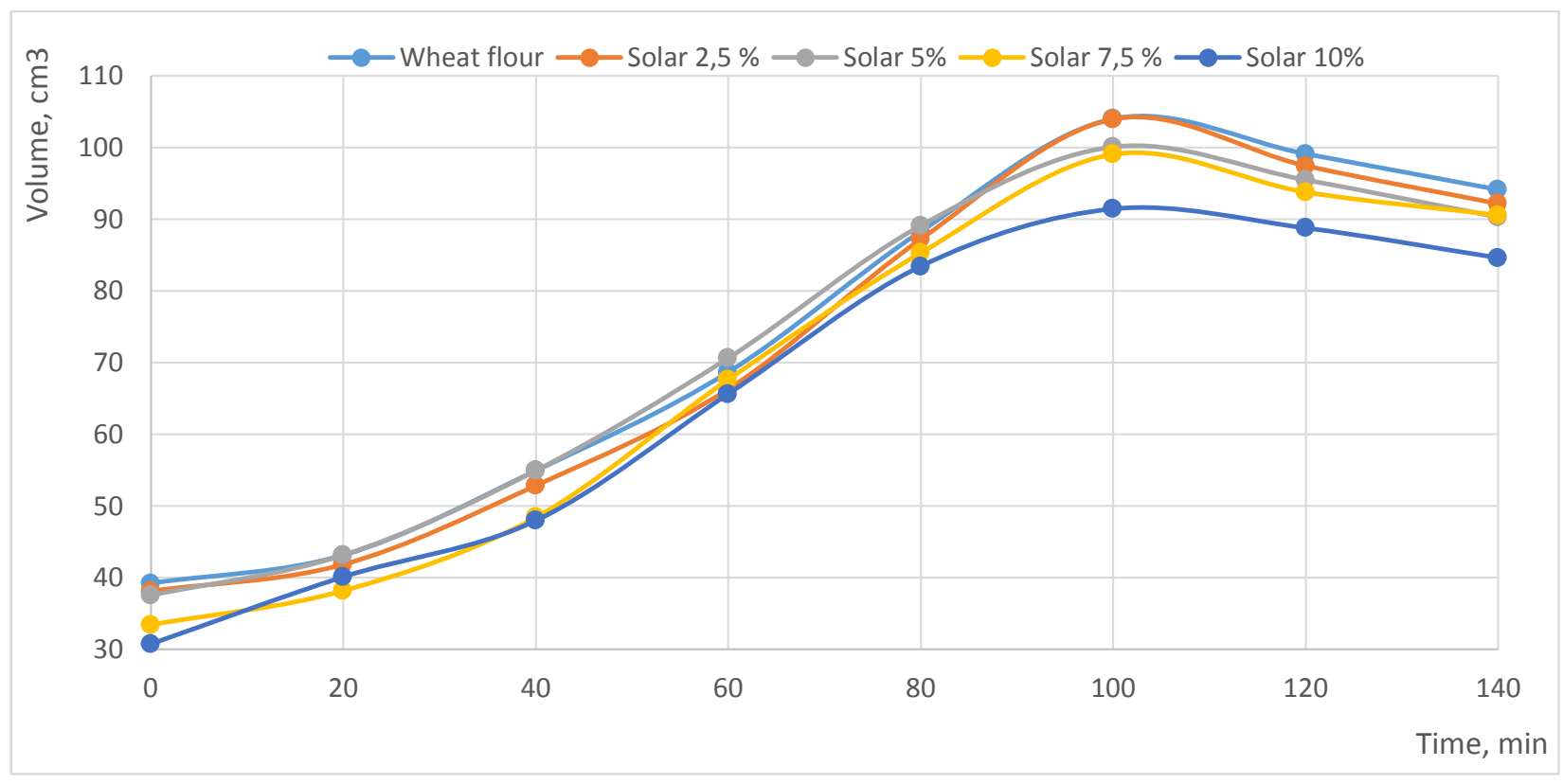

Figure 4a. The impact of the addition of Jerusalem artichoke flour on the volume of the dough during fermentation: dough from wheat flour (control sample,) dough from wheat flour-Jerusalem artichoke Solar variety in concentration of $2,5 \%, 5 \%, 7,5 \%$ and $10 \%$.

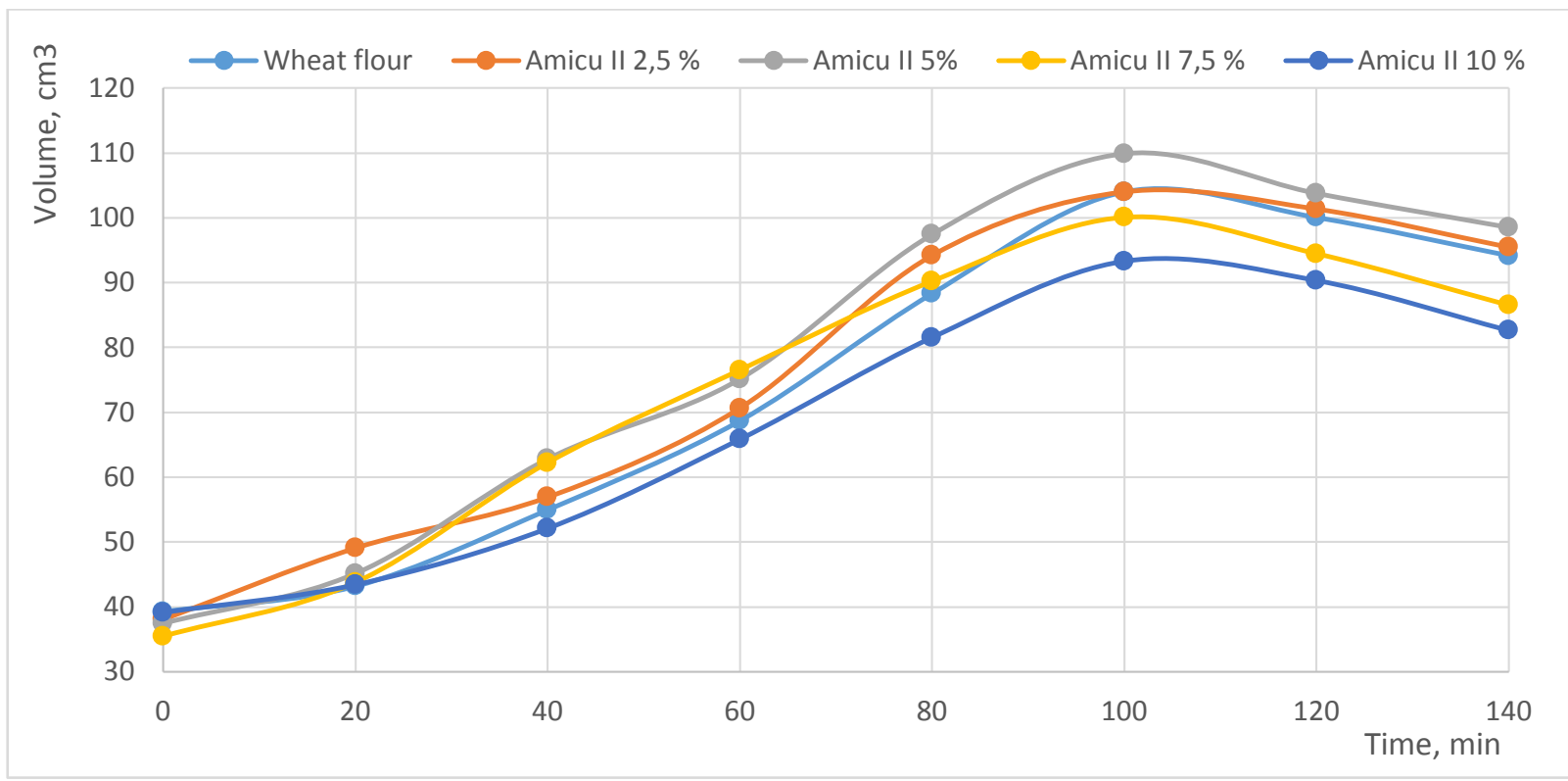

Figure $4 \mathbf{b}$. The impact of the addition of Jerusalem artichoke flour on the volume of the dough during fermentation: dough from wheat flour (control sample,) dough from wheat flour-Jerusalem artichoke Amicu II variety in concentration of 2,5\%, 5\%, 7,5\% and $10 \%$. 


\subsection{The impact of the addition of Jerusalem artichoke flour on the color of the crust}

A good quality baking dough must have a certain resistance to mechanical work and be able to properly retain a maximum of gas during fermentation and baking, so as to have adequate rheological properties (hardness, extensibility, elasticity, strength). The rheological properties of the dough, with the addition of Jerusalem artichoke flour, depend on the quantity and quality of proteins present.

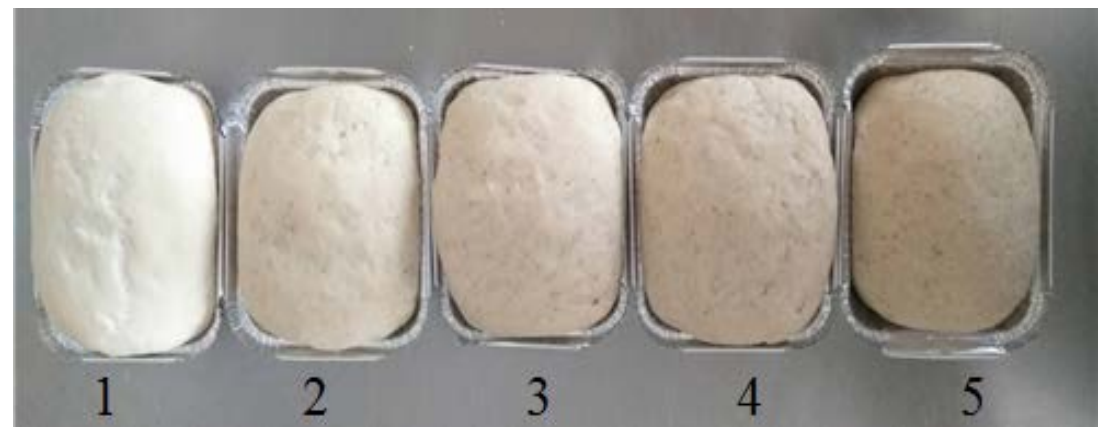

Figure 5. The impact of addition, in different concentrations, of Jerusalem artichoke flour on the quality of the bread (degree of replacement of wheat flour with that of Jerusalem artichoke, \%): 1 - control sample, 0\%; 2 - 2,5 \% 3-5,0 \% 4-7,5\% ; 5-10,0\%.

\subsection{The impact of wheat flour substitution with Jerusalem artichoke flour on bread volume}

Replacing wheat flour with Jerusalem artichoke flour up to $10 \%$ the color of the bread crust becomes darker. Several authors have attributed the coloring of the bread crust to Maillard reactions involving simple sugars and amino acids in the composition of Jerusalem artichoke.

The low content of simple sugars and the low fermentation power lead to the bread with the light color of the crust. While the bread with darker shades is due to the presence of excess of simple sugars obtained by changing the starch.

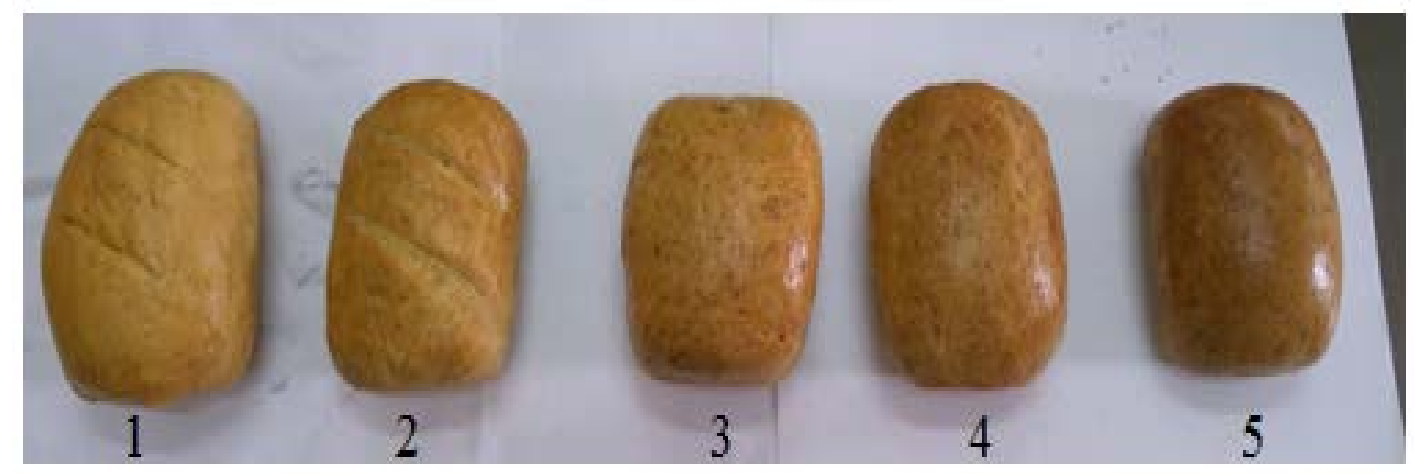

Figure 6. The impact of addition, in different concentrations, of Jerusalem artichoke flour on the color of the crust (degree of replacement of wheat flour with that of Jerusalem artichoke, \%): 1 - control sample, 0\%; 2 - 2,5 \% 3-5,0 \%; 4-7,5\%; 5-10,0\%.

The substitution of wheat flour with Jerusalem artichoke flour (up to 10\%) also leads to a change in the color of the bread crumbs, from yellowish white to gray.

Also, the texture of the core becomes less aerated and the alveoli they grow irregularly, they are more compact, so we can say that increasing the concentration of Jerusalem artichoke flour will lead to poor bread quality. 
3.7 Influence of Jerusalem artichoke flour addition on bread acidity compared to dough acidity

The acidity of bread is caused by the acidic substances in the flour with which the dough was prepared and by the acids that appear in the dough, as a result of the activity of yeasts and bacteria: carbon dioxide, lactic acid, succinic, malic and volatile acids - acetic and formic.

Under the action of the formed acids, the processes of hydration and peptization of amino acids intensify, the formation of the specific taste and aroma of the bread takes place.

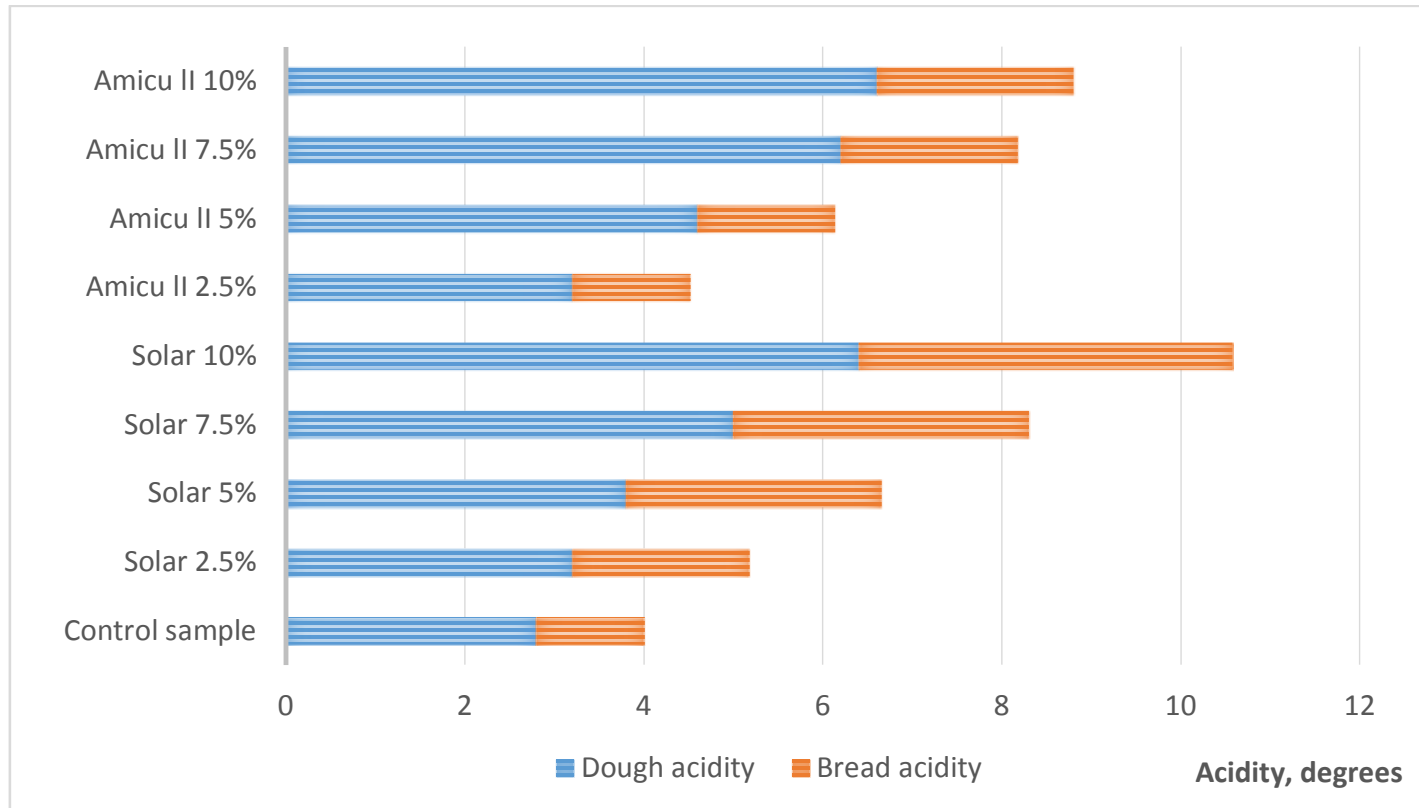

Figure 7. The influence of Jerusalem artichoke flour addition on the change in the acidity of bread compared to the acidity of the dough.

Due to the appearance of these acids there is an increase in the acidity of the dough during fermentation. About $60 \%$ of the acidity of the dough is due to lactic acid. The initial and final acidity of the dough is influenced by the degree of extraction of the flour, its consistency, the temperature and the duration of the leavening.

The final acidity of semi-finished products is an index of their maturity, being an important and controllable parameter, which directly influences their finite properties [21].

\subsection{Sensory analysis}

Organoleptic analysis of bread quality included assessment of the appearance of bread, symmetry of shape, volume, color and structure of the crust, color, elasticity and porosity of the core, taste, smell, signs of microbial spoilage and the presence of foreign bodies.

Table 4

Appreciation of the external appearance of the bread

\begin{tabular}{lccccc}
\hline Sen sory feature & $\mathbf{0 \%}$ & $\mathbf{2 , 5} \%$ & $\mathbf{5 \%}$ & $\mathbf{7 , 5} \%$ & $\mathbf{1 0 \%}$ \\
\hline $\begin{array}{l}\text { The shape and } \\
\text { volume of the product }\end{array}$ & 4,0 & 4,0 & 4,0 & 4,5 & 3,0 \\
\hline
\end{tabular}


Continuation Table 4

\begin{tabular}{|c|c|c|c|c|c|}
\hline $\begin{array}{l}\text { The color and } \\
\text { appearance of the } \\
\text { crust }\end{array}$ & 4,0 & 4,0 & 4,0 & 3,5 & 2,0 \\
\hline $\begin{array}{l}\text { Degree of baking. } t \\
\text { condition and } \\
\text { appearance of the } \\
\text { core }\end{array}$ & 6,0 & 6,0 & 6,0 & 5,0 & 4,0 \\
\hline $\begin{array}{l}\text { Core porosity and } \\
\text { pore structure }\end{array}$ & 6,0 & 5,0 & 5,0 & 5,5 & 4,0 \\
\hline Flavor & 4,0 & 3,0 & 4,0 & 3,5 & 2,0 \\
\hline Taste & 5,0 & 5,0 & 6,0 & 5,5 & 3,0 \\
\hline Total & 29,0 & 27,0 & 29,0 & 27,5 & 18,0 \\
\hline
\end{tabular}

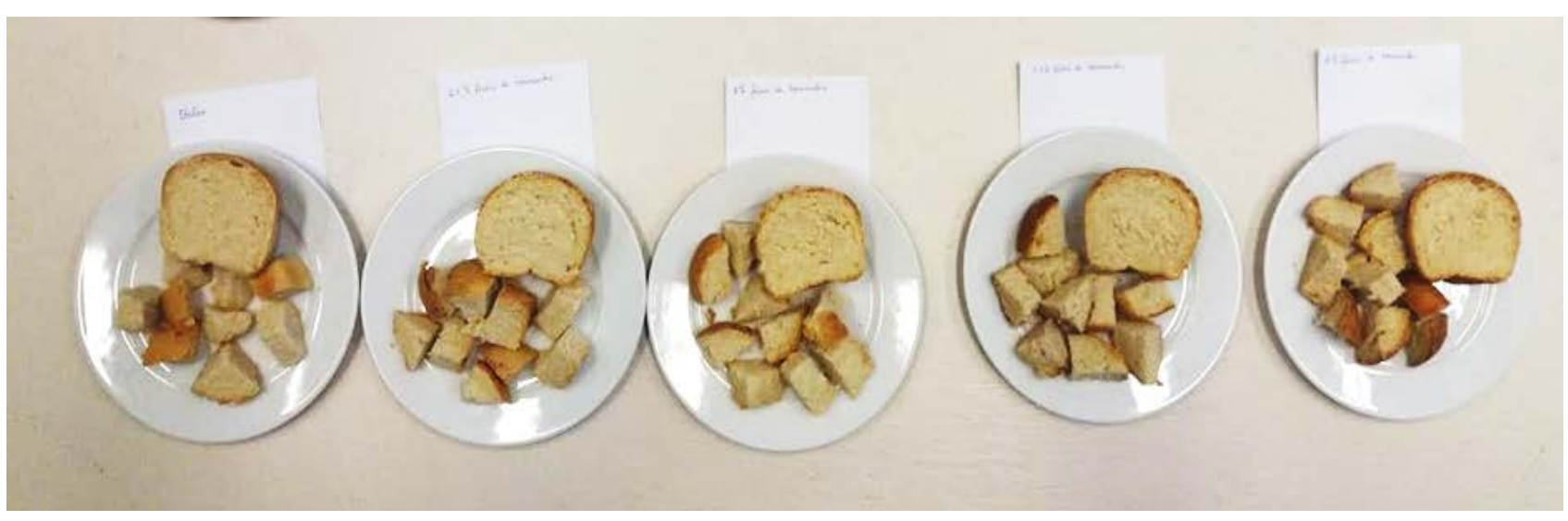

Figure 8. Organoleptic evaluation of bread quality

with the addition of Jerusalem artichoke flour.

The results of the sensory evaluation showed very good qualities for the products made with the addition of Jerusalem artichoke flour of $5 \%$. Samples of mixed flour bread with a Jerusalem artichoke flour content over 7.5 and even $10 \%$ had lower organoleptic indices, including lower shape and volume, cracked surface, pronounced flavor.

\section{Conclusions}

The use of Jerusalem artichoke flour in the manufacture of bread leads to improved chemical properties and quality of bread. These benefits were more significant at the $5 \%$ concentration of Jerusalem artichoke flour in bread. These changes are due to the high content of essential amino acids in Jerusalem artichoke tubers, such as histidine, isoleucine, methionine, phenylalanine and valine.

The organoleptic characteristics of the bread were improved by substituting wheat flour with Jerusalem artichoke flour up to $5 \%$. Thus, the color of the bread crust becomes darker due to Maillard reactions involving simple sugars and amino acids in the composition of Jerusalem artichoke. 
As the concentration of Jerusalem artichoke flour increases, the gluten concentration decreases, which leads to a decrease in the elasticity, porosity and texture of the dough.

The substitution of wheat flour with Jerusalem artichoke flour (10\%) also leads to changes in the color and texture of the bread core, giving a poor quality of the bread.

As a result of this study, we recommend adding $5 \%$ Jerusalem artichoke flour to wheat bread to obtain a product rich in micro and macronutrients with better organoleptic properties and a longer shelf life, which positively influences human health.

The use of Jerusalem artichoke flour in bakery products represents an alternative direction in food development.

Acknowledgements: The research was funded by State Project 20.80009.5107.09 "Improving of food quality and safety through biotechnology and food engineering", running at Technical University of Moldova.

\section{References}

1. Marian G., Muntean A., Gudîma A., Tiţei V., Pavlenco A. Analiza comparativă a biomasei obţinute din culturi energetice. În: Ştiinţa agricolă, 2014, 2. pp. 70-74.

2. Fellin W. Analyzying Uncertainty in Engineering; Berlin. Germany: Springer, 2005, pp.251.

3. Titei V., Teleuta A. Specii perene şi soiuri de plante pentru fondarea plantatiilor energetice în Republica Moldova. In :Intellectuss, 2014, 4. pp.86-92.

4. Baltacioğlu C., Esin A. Chips Production from Jerusalem Artichoke (Helianthus tuberosus L.) In: Food and Nutrition Sciences, 2012, 3, pp.1321-1328.

5. Gedrovica I., Karklina D. Influence of Jerusalem Artichoke Powder on the Nutritional Value of Pastry Products. In: World Academy of Science. Engineering and Technology International Journal of Biological. Biomolecular. Agricultural. Food and Biotechnological Engineering, 2012, 6(7).

6. Nikitin P. V., Novikova I. L. A method for the production of un-clarified and clarified concentrated jerusalem artichoke juice: Russian Federation Patent 2444914, 2006.

7. Radovanovic A., Milovanovic O., Kipic M., Ninkovic M., Cupara S. Characterization of Bread Enriched with Jerusalem Artichoke Powder Content. In: Journal of Food and Nutrition Research, 2014, 2(12), pp.895-898.

8. Sumera Z., Narjis N., Saliha N., Mateen A. and Abdul M. K. Analysis of Selected Amino Acids in Different Varieties of Wheat Available in Punjab. Pakistan. In: Hindawi Publishing Corporation Chromatography Research International, 2014, pp.1-6.

9. Dao T.H., Zhang J., Bao J. Characterization of inulin hydrolyzing enzyme(s) in commercial glucoamylases and its application in lactic acid production from Jerusalem artichoke tubers (Jat). In: Bioresour. Technol, 2013, 148, pp.157-162.

10. Cheng X., Dong Y., Su P., Xiao X. Improvement of the fermentative activity of lactic acid bacteria starter culture by the addition of Mn. In: Appl Biochem Biotechnol, 2014, 174(5), pp.1752-1760.

11. Choi HY., Ryu HK., Park KM., Lee EG., Lee H., Kim SW. Choi ES. Direct lactic acid fermentation of Jerusalem artichoke tuber extract using Lactobacillus paracasei without acidic or enzymatic inulin hydrolysis. In: Bioresour Technol, 2012, 114, pp.745-747.

12. Safronova T. N. A new type of jerusalem artichoke processing product. In: Journal of the Krasnoyarsk State Agrarian University, 2010, 9, pp. 168-174.

13. Kupin G. A., Naimushina E. G., Zaiko G. M. Fruit and vegetable puree for diabetic patients: Russian Federation Patent 2202231, 2003.

14. Artyukh L. I., Shazzo R. I., Pavlova G. N., Erashova L. D., Alyokhina L. A., Ermolenko R. S. A method for the production of puree-like products based on jerusalem artichoke for dietary nutrition: Russian Patent 2362324, 2009.

15. Amirkhanov K. Zh. Complex use of meat and vegetable raw materials in the production of molded meat products. In: Journal of the Altai State Agrarian Universit, 2009, 11, pp. 76-80.

16. Ustinova A.V. Jerusalem artichoke and its processed products in functional meat products. In: Meat industry, 2012, 2, pp.19-21.

17. Takeuchi J., Nagashima T. Preparation of dried chips from Jerusalem artichoke (Helianthus tuberosus L.) tubers and analyşis of their functional properties. In: Food Chemistry, 2011, 126, pp.922-926. 
18. Vinnitskaya V. F. Development of technology for processing jerusalem artichoke for the production of functional bread products. In: Journal of the Michurinsk State Agrarian University, 2013, 2, pp. 59-63.

19. Catană L., Catană M., Iorga E. Valorification of jerusalem artichoke tubers (Helianthus tuberosus) for achieving of functional ingredient with high nutritional value. In:"Agriculture for life. Life for agriculture" conference proceeding, 2018, 102478, PP.276-283.

20. Kuznetsova L. I. Scientific basis of bread technologies using rye flour on sourdough with improved biotechnological properties: Ph.D. Thesis. Moscow(Russia): State Research Institute of the Baking Industry of the Russian Agricultural Academy, St. Petersburg 2010.

21. Mezenova O. YA. Modeling the recipe of diabetic shortbread cookies with the addition of stevia and jerusalem artichoke. In: Journal of the International Academy of Cold, 2013, 4, pp. 23-26..

22. Tertychnaya T. N. Increasing the nutritional value of cupcakes through the use of promising plant additives. In: Journal of the Voronezh State Agrarian University, 2013, 1, pp. 291-297.

23. Dajdaleva M. I. Development of technologies and recipes for diabetic sugary confectionery products using products of processing of Jerusalem artichoke tubers. In: Food technology, 2011, 2-3, pp.66-68.

24. Kazakova O. N. Optimization of the recipe of shortbread cookies for diabetics with vegetable additives. In: Food technolog, 2012, 1, pp.53-56.

25. Umirzakova S. H. Jerusalem artichoke in the production of galette. In: Journal of the Almaty Technological University, 2012, 4. pp. 69-73.

26. Anuarul statistic al Republicii Moldova (Statistical Yearbook of the Republic of Moldova) (In Romanian). National Bureau of Statistics of the Republic of Moldova: Chisinau. Republic of Moldova, 2018, pp. 249.

27. ISO 763:2003 Fruit and vegetable products - Determination of ash insoluble in hydrochloric acid

28. ISO 6540:2010 MAIZE - Determination of moisture content (on milled grains and on whole grains)

29. Lawless H.T., Heymann H. Sensory Evaluation of Food. Principles and Practices; ed.Springer, Berlin. Germany, 2010, pp.596.

30. Chandrasekhar U. Determination of Moisture in Dehydrated Vegetables. In:ISI Handbook of Food Analysis (Part VIII); Indian Standards Institution: New Delhi. India. 1984, pp. 12.

31. Scafetta N. An Entropic Approach to the Analysis of Time Series. Ph.D. Thesis. University of North Texas. Denton. TX. (USA), 2001.

32. Siminiuc R., Țurcanu D. Impact of artisanal technologies on the quality indices of the sweet bread. In: Food Systems, 3(3), 2020. 